Jurnal Riset Manajemen Sains Indonesia (JRMSI) | Vol 12, No. 2, 2021 e-ISSN: 2301-8313 http://doi.org/10.21009/JRMSI

DOI: doi.org/10.21009/JRMSI.012.2.04

\title{
ANALISIS PENGARUH WORK-FAMILY CONFLICT, FAMILY-WORK CONFLICT TERHADAP STRES KERJA DAN DAMPAKNYA TERHADAP KEPUASAN HIDUP PEKERJA FRONT OFFICE HOTEL DI INDONESIA
}

\author{
Elissa Dwi Lestari \\ Fakultas Bisnis Universitas Multimedia Nusantara \\ Email: elissa.lestari@umn.ac.id \\ Sugiarto Suhendar \\ Fakultas Bisnis Universitas Multimedia Nusantara \\ Email: sugiarto.suhendar@student.umn.ac.id \\ Septi Fahmi Choirisa \\ Fakultas Bisnis Universitas Multimedia Nusantara \\ Email: septi.choirisa@umn.ac.id \\ Nosica Rizkalla \\ Fakultas Bisnis Universitas Multimedia Nusantara \\ Email: nosica.rizkalla@umn.ac.id \\ Purnamaningsih Purnamaningsih \\ Fakultas Bisnis Universitas Multimedia Nusantara \\ Email: purnamaningsih@umn.ac.id
}

\begin{abstract}
ABSTRAK
Pelayanan yang prima merupakan kunci keberhasilan di industri hotel. Oleh karena itu, karyawan front office di hotel, sebagai gambaran citra perusahaan sekaligus industri dituntut untuk menunjukkan pelayanan yang terbaik secara konsisten dari waktu-waktu. Untuk memenuhi tuntutan pekerjaan maka karyawan front office bekerja dengan waktu yang panjang dan tidak menentu. Hal ini membuat karyawan front office mengalami konflik peran dan kesulitan untuk menyeimbangkan tuntutan antara pekerjaan dengan keluarga. Konflik peran ini membuat pekerjaan front office memiliki tingkat stres kerja yang tinggi. Tingkat stress yang tinggi membuat keterlibatan di pekerjaan menjadi kurang maksimal yang akhirnya berdampak pada sikap ketidakpuasan terhadap hidup secara umum. Di Indonesia, penelitian mengenai kepuasan hidup karyawan front office hotel masih belum cukup banyak ditemui padahal sikap ketidakpuasan terhadap hidup karyawan dapat berdampak pada sikap dan pelayanan di tempat kerja. Oleh karena itu, penelitian ini bertujuan untuk bertujuan untuk mengetahui pengaruh Work-Family Conflict, Family-Work Conflict terhadap stres kerja dan Kepuasan hidup pekerja
\end{abstract}


Jurnal Riset Manajemen Sains Indonesia (JRMSI) | Vol 12, No. 2, 2021 e-ISSN: 2301-8313 http://doi.org/10.21009/JRMSI

front office hotel di Indonesia. Penelitian ini menggunakan teknik sampling purposive terhadap 121 pekerja front office hotel di Indonesia. Hasil analisis data menggunakan SEM-PLS menunjukkan bahwa Work-Family Conflict dan Family-Work Conflict berpengaruh positif terhadap stres kerja, dan stres kerja yang tinggi akan berpengaruh negatif terhadap kepuasan hidup. Lebih lanjut, hasil analisis menunjukan Work-Family Conflict dan Family-Work Conflict tidak berpengaruh terhadap kepuasan hidup. Mengingat pentingnya tingkat kepuasan hidup terhadap sikap layanan pekerja, maka Manajemen hotel diharapkan untuk membuat kebijakan yang memfasilitasi tuntutan keluarga dan pekerjaan untuk mengurangi stres kerja.

Kata Kunci: Work-Family Conflict, Family-Work Conflict, stres kerja , kepuasan hidup, pekerja front office hotel

\section{PENDAHULUAN}

Sektor pariwisata memegang peranan yang sangat penting dalam perekonomian Indonesia karena turut berkontribusi dalam meningkatkan penerimaan devisa negara, pendapatan daerah, pengembangan wilayah, maupun dalam penyerapan investasi dan tenaga kerja serta pengembangan usaha yang tersebar di berbagai pelosok wilayah di Indonesia (Kemenparekraf.go.id, 2019). Dari sisi penerimaan negara, kontribusi sektor pariwisata terhadap devisa negara terus menerus meningkat. Penerimaan devisa negara yang berasal dari sektor pariwisata mencapai Rp229,5 triliun pada tahun 2018. Angka ini meningkat 15,4 persen dibandingkan kontribusi paada tahun 2017. Dari sisi penyerapan tenaga kerja, berdasarkan data Kemenparekraf, sektor pariwisata menyerap tenaga kerja sebanyak 12,7 juta orang atau menyumbang 10 persen dari total penduduk bekerja di Indonesia (CNN Indonesia, 2020). Perkembangan sektor pariwisata ini turut berdampak pada peningkatan kebutuhan pelanggan akan hotel.

Data Badan Pusat Statistik Indonesia memperlihatkan ada nya pertumbuhan jumlah hotel di Indonesia. Pada tahun 2018, terdapat 3314 hunian hotel di Indonesia. Jumlah ini naik sebesar 6.095\% menjadi 3516 pada tahun 2019 (BPS, 2018, 2019).

Dalam industri hotel, agar tetap kompetitif dan berdaya saing unggul diperlukan upaya untuk terus menerus meningkatkan kualitas pelayanan terhadap pelanggan. Tingkat kepuasan pelanggan yang tinggi adalah kunci kesuksesan bisnis pariwisata, terutama untuk bisnis hospitality (Dominici \& Guzzo, 2010; Khan et al., 2015).

Permintaan pelanggan akan pelayanan yang prima dari waktu ke waktu mengakibatkan hotel untuk terus menerus berkompetisi satu sama lain agar dapat memenuhi ekspektasi tersebut. Untuk mencapai harapan pelanggan akan pelayanan yang terbaik maka pekerja front 
Jurnal Riset Manajemen Sains Indonesia (JRMSI) | Vol 12, No. 2, 2021 e-ISSN: 2301-8313 http://doi.org/10.21009/JRMSI

office, sebagai penggambaran citra perusahaan maupun industri hospitality, dituntut untuk secara konsisten memperlihatkan kualitas pelayanan yang terbaik dari waktu ke waktu (Karatepe \& Karadas, 2016; Lestari \& Yuwono, 2020; Mansour \& Tremblay, 2016).

Tuntutan pekerjaan front office hotel yang tinggi untuk menciptakan kepuasan pelanggan telah membuat mereka memiliki waktu kerja yang panjang dan tidak menentu (Coughlan et al., 2014; Zhao et al., 2014). Kondisi ini mengakibatkan pegawai front office hotel memiliki tingkat Stres Kerja yang tinggi (Karatepe \& Uludag, 2008; Mansour \& Tremblay, 2016; Zhao et al., 2014).

Tuntutan industri dan organisasi untuk menampilkan kesempurnaan dalam layananan juga mengakibatkan pekerja front office hotel mengalami konflik peran, dimana mereka mengalami kesulitan untuk menyeimbangkan dan memenuhi tuntutan pekerjaan dengan tuntutan yang datang dari keluarga mereka (Esitti et al., 2015; Mansour \& Tremblay, 2016; Zhao et al., 2014). Saat karyawan front office tidak dapat tidak dapat menyeimbangkan antara tanggung jawab di pekerjaan dengan tanggung jawab di rumah maka mereka tidak bisa engage di pekerjaan dan menunjukkan sikap ketidakpuasan terhadap hidup secara umum (Karatepe \& Karadas, 2016). Dalam konteks penelitian ini, kualitas kehidupan kerja seperti tuntutan pekerjaan yang tinggi dan stres kerja, dan kualitas kehidupan di luar pekerjaan seperti kesempatan untuk menghabiskan waktu bersama keluarga akan berdampak pada kepuasan hidup seseorang. Dalam konteks organisasi, kualitas hidup individu bekerja akan mempengaruhi tingkat komitmen untuk bekerja dalam organisasi (Itzhaki et al., 2015).

Kendati, secara umum, stres kerja merupakan sesuatu yang lumrah terjadi dan dirasakan oleh pekerja di industri hospitality terutama hotel, dan sudah banyak penelitian terdahulu yang mengkaitkan hubungan antara stres kerja dengan konflik peran dalam bentuk Work-Family Conflict dan Family-Work Conflict (Jamadin et al., 2015; Mansour \& Tremblay, 2016). Kebanyakan penelitian terdahulu mengenai hal ini banyak dikaitkan dengan aspek kehidupan pekerjaan seperti tingkat kualitas layanan (Mansour \& Mohanna, 2018), tingkat kepuasan kerja (Armstrong et al., 2015; Vickovic \& Morrow, 2020) dan komitmen organisasi (Vickovic \& Morrow, 2020). Nyatanya sampai saat ini, terutama untuk konteks Indonesia, masih belum banyak penelitian yang mengeksplorasi hubungan antara stres kerja dan konflik peran (Work-Family Conflict serta Family-Work Conflict) dengan kehidupan di luar 
Jurnal Riset Manajemen Sains Indonesia (JRMSI) | Vol 12, No. 2, 2021 e-ISSN: 2301-8313 http://doi.org/10.21009/JRMSI

pekerjaan seperti tingkat kepuasan hidup secara umum. Padahal kehidupan di luar pekerjaan akan berdampak pada kualitas kinerja individu di organisasi.

Oleh karena itu, studi yang kami lakukan akan berkontribusi untuk memperkaya literatur mengenai pengaruh variabel kehidupan di tempat kerja terhadap kepuasan hidup. Kajian ini merupakan bidang penting yang perlu dieksplorasi baik untuk alasan teoritis maupun praktis oleh pengelola industri hotel. Kepuasan hidup yang dirasakan seorang pekerja akan mendorong terciptanya keterbukaan pikiran, meningkatkan kreativitas dan perilaku prososial serta mendorong pekerja untuk melakukan interaksi sosial di tempat yang lebih baik (Lambert et al., 2018). Dimana interaksi sosial, terutama interaksi dengan pelanggan merupakan kunci sukses industri hotel untuk menciptakan tingkat kepuasan berbasis pengalaman di industri hotel (Khan et al., 2015).

\section{Rumusan Masalah}

Berdasarkan latar belakang masalah yang telah diuraikan sebelumnya, maka terdapat lima persoalan penelitian yang ingin dibahas sebagai berikut: 1). Apakah Work-Family Conflict berpengaruh terhadap Stres Kerja di kalangan pekerja Front Office di Indonesia? 2). Apakah Family-WorkConflict berpengaruh terhadap Stres Kerja di kalangan pekerja Front Office di Indonesia? 3). Apakah Work-Family Conflict berpengaruh terhadap Kepuasan Hidup pekerja Front Office di Indonesia? 4). Apakah Family-WorkConflict berpengaruh terhadap Kepuasan Hidup pekerja Front Office di Indonesia? 5). Apakah Stres Kerja berpengaruh terhadap Kepuasan Hidup pekerja Front Office di Indonesia?

\section{Tujuan Penelitian}

Adapun tujuan penelitian ini adalah: 1). Untuk mengetahui pengaruh Work-Family Conflict terhadap Stres Kerja di kalangan pekerja Front Office di Indonesia. 1). Untuk mengetahui pengaruh Family-Work Conflict terhadap Stres Kerja di kalangan pekerja Front Office di Indonesia. 2). Untuk mengetahui pengaruh Work-Family Conflict terhadap 
Jurnal Riset Manajemen Sains Indonesia (JRMSI) | Vol 12, No. 2, 2021 e-ISSN: 2301-8313 http://doi.org/10.21009/JRMSI

Kepuasan Hidup pekerja Front Office di Indonesia. 3). Untuk mengetahui pengaruh FamilyWork Conflict terhadap Kepuasan Hidup pekerja Front Office di Indonesia. 4). Untuk mengetahui pengaruh Stres Kerja terhadap Kepuasan Hidup pekerja Front Office di Indonesia.

\section{TELAAH PUSTAKA}

\section{Work-Family Conflict (WFC) dan Family-Work Conflict (FWC)}

Kahn et al., (1964) menjelaskan konsep Work-Family Conflict dengan menggunakan kerangka teori peran. Menurut kerangka teori peran, faktor penentu utama dari perilaku individu adalah ekspektasi perilaku yang orang lain miliki terhadap dirinya. Teori peran menelaah ekspektasi yang dimiliki oleh masing-masing peran yang dimiliki oleh individu di kehidupannya dapat menghasilkan inter-role conflict (konflik antar peran). Konflik antar peran ini terjadi ketika terdapat tekanan-tekanan yang berasal dari lingkungan sosial, di mana individu dituntut untuk memenuhi semua ekspektasi atau tuntutan yang timbul karena beragamnya peran yang dimilikinya. karena masing-masing peran memerlukan waktu, energi dan komitmen maka tak jarang terjadi konflik ekspektasi antar peran yang dimiliki oleh individu. Oleh karena itu, menurut pandangan ini, Work-Family Conflict merupakan bentuk dari konflik antar peran di bidang pekerjaan dan peran di lingkungan keluarga yang dimiliki oleh individu.

Konflik antar peran kemudian didefenisikan lebih lanjut oleh Greenhaus \& Beutell (1985) sebagai tekanan yang tercipta ketika individu kesulitan untuk menyeimbangkan tanggung jawab dan peran sebagai anggota organisasi dan sebagai anggota keluarga. Di mana, partisipasi peran individu dalam pekerjaan (keluarga) terganggu karena tuntutan peran keluarga (kerja) yang harus dipenuhi pada saat yang hampir bersamaan. Pertentangan serta tekanan konflik peran ini kemudian semakin meningkat sehingga menyebabkan efektivitas pada salah satu peran terhambat oleh aktivitas peran yang lainnya (konflik peran yang bersifat timbal balik). Studi yang dilakukan oleh Frone et al., (1992) memperlihatkan bahwa konflik peran antara pekerjaan dan keluarga ataupun keluarga dan pekerjaan dipicu oleh antesenden maupun tekanan yang berbeda. Di mana konflik pekerjaan dan keluarga muncul sebagai akibat Stres Kerjaor dan job involvement, sebaliknya, konflik keluarga dan pekerjaan muncul sebagai akibat family stressor dan family involvement. 
Jurnal Riset Manajemen Sains Indonesia (JRMSI) | Vol 12, No. 2, 2021 e-ISSN: 2301-8313 http://doi.org/10.21009/JRMSI

Netemeyer, Boles, \& McMurrian, (1996) mengkategorisasi konflik peran dalam pekerjaan menjadi Work-Family Conflict dan Family-Work Conflict. Work-Family Conflict didefinisikan sebagai suatu bentuk konflik peran, yang secara umum terjadi karena tuntutan pekerja memaksa seseorang untuk menghabiskan lebih banyak waktu untuk menyelesaikan pekerjaannya yang akhirnya mengganggu tanggung jawab seseorang sebagai anggota keluarga. Sedangkan, menurut Ten Brummelhuis et al., (2011), The Work-Family Conflict adalah produk dari suatu mekanisme di mana pekerjaan melibatkan sumber daya pribadi yang habis dan menghambat pencapaian dalam domain keluarga.

Ada tiga kategori WFC: konflik berbasis waktu (time-based), konflik berbasis ketegangan (strain-based), dan konflik berbasis perilaku (behavior-based). WFC berbasis waktu muncul ketika penjadwalan shift kerja atau jumlah waktu yang dihabiskan di tempat kerja mengganggu kehidupan rumah tangga. Konflik berbasis perilaku terjadi ketika tuntutan sikap dan perilaku yang dari suatu pekerjaan meresap dan terbawa sampai ke dalam kehidupan rumah tangga dan dinamika keluarga. Sedangkan, Ketika tuntutan dan stres dari pekerjaan secara negatif mempengaruhi kehidupan rumah tangga, ini dianggap konflik berbasis ketegangan (Greenhaus \& Beutell, 1985; Netemeyer et al., 1996).

Sedangkan, Family-Work Conflict didefenisikan sebagai suatu bentuk konflik peran yang terjadi ketika tuntutan peran dalam keluarga membuat seseorang mencurahkan lebih banyak waktu yang dimilikinya pada urusan keluarga. Hal ini membuat individu kesulitan untuk menyelesaikan tuntutan pekerjaannya dengan baik (Netemeyer et al., 1996). Lebih lanjut, Bagger \& Li (2012) menggambarkan Family-Work Conflict sebagai konflik yang disebabkan oleh tuntutan domain keluarga yang membatasi kemampuan seseorang untuk memenuhi tanggung jawab pekerjaan. Jika tidak dapat diatasi dengan baik maka konflik peran dalam bentuk Work-Family Conflict dan Family-Work Conflict dapat menimbulkan kelelahan emosional (Lestari \& Yuwono, 2020) yang dapat berpengaruh terhadap kinerja.

\section{Stres Kerja (Stres Kerja)}

Stres secara psikologis didefinisikan sebagai reaksi individu terhadap lingkungannya ketika terjadi ancaman akan hilangnya sumber daya, kehilangan sumber daya dan, atau disebabkan oleh kurang sebandingnya sumber daya yang didapat jika dibandingkan dengan investasi sumber daya yang sudah dihabiskan (Hobfoll, 1989). Menurut Sulsky \& Smith 
Jurnal Riset Manajemen Sains Indonesia (JRMSI) | Vol 12, No. 2, 2021 e-ISSN: 2301-8313 http://doi.org/10.21009/JRMSI

(2005), stress mengacu pada reaksi seseorang ketika dihadapkan pada faktor lingkungan yang memaksakan suatu tuntutan fisik dan / atau psikologis khusus.

Cox (1993) mendefinisikan stres kerja sebagai hasil dari persepsi seseorang tentang ketidakseimbangan antara tuntutan pekerjaan dengan kemampuan mereka untuk menangani tuntutan pekerjaan yang dibebankan kepada mereka. Health \& Safety Executive (HSE) (1995) mendefiniskan stres kerja sebagai tekanan dan tuntutan pekerjaan yang ekstrim yang diberikan pada seseorang di luar kemampuannya. Sedangkan Stranks (2005) mendefinisikan stres kerja sebagai suatu keadaan psikologis yang dapat menyebabkan individu berperilaku disfungsional di tempat kerja nya dan merupakan bentuk reaksi seseorang akan ketidakseimbangan antara tuntutan pekerjaan dan kemampuan mereka untuk mengatasinya. Pada dasarnya, stres di tempat kerja muncul ketika orang mencoba untuk mengatasi tugas, tanggung jawab, atau bentuk tekanan lain yang terkait dengan pekerjaan mereka, tetapi mengalami kesulitan, ketegangan, kecemasan dan kekhawatiran dalam upaya mengatasinya.

\section{Kepuasan Hidup (Life Satisfaction)}

Kepuasan Hidup (life satisfaction) merupakan suatu proses penilaian, sebuah kognisi. Kepuasan hidup merupakan suatu penilaian global seseorang mengenai tingkat kualitas hidupnya berdasarkan kriteria tertentu. Dalam hal ini, seberapa puas seseorang terhadap hidupnya saat ini, harus didasarkan pada standar kebahagiaan hidup yang ia telah tetapkan sendiri. Penilaian individual mengenai tingkat kepuasan terhadap hidupnya kemudian akan dibandingkan dengan standard situasi yang dipandang baik secara umum (Diener et al., 1985). Kepuasan hidup sering dipandang sebagai hasil dari kepuasan dengan berbagai aspek kehidupan, seperti kesehatan, sosial, waktu luang, keluarga, dan pekerjaan (Lambert et al., 2018).

Tingkat kepuasan hidup dapat dilihat dari dua perspektif yakni pendekatan top-down dan pendekatan bottom-up. Pendekatan top-down yang memandang kepuasan hidup sebagai fungsi dari sifat-sifat manusia yang stabil, seperti kepribadian. Sedangkan, pendekatan bottomup menggambarkan hubungan antara domain kerja dan kepuasan hidup. Pendekatan bottomup memandang kepuasan hidup sebagai bagian dari fungsi dari domain kehidupan, termasuk didalamnya, kehidupan pekerjaan. Dalam konteks pendekatan bottom-up, kualitas dari kehidupan kerja (stres kerja dan tingkat kepuasan terhadap karir dan pekerjaan), kualitas dari 
Jurnal Riset Manajemen Sains Indonesia (JRMSI) | Vol 12, No. 2, 2021 e-ISSN: 2301-8313 http://doi.org/10.21009/JRMSI

kehidupan di luar pekerjaan (tingkat kepuasan seseorang terhadap kesehatan, keluarga dan leisure) serta perasaan keberhargaan diri merupakan mekanisme dimana pekerjaan berhubungan erat dengan tingkat kepuasan hidup seseorang (Erdogan et al., 2012; Lambert et al., 2018)

\section{MODEL PENELITIAN}

Uraian dari seluruh variabel yang diangkat dalam penelitian ini, maka dapat dibuat kerangka model penelitian seperti gambar berikut:

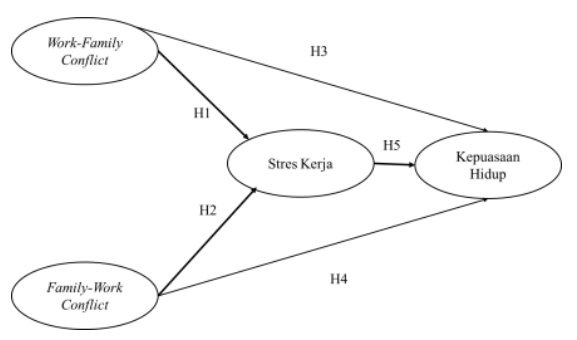

\section{Gambar 1. Kerangka Penelitian}

Sumber: Model Penelitian (2020)

\section{Perumusan Hipotesis Penelitian}

\section{Work-Family Conflict (WFC) berpengaruh positif terhadap Stres Kerja}

Penelitian yang dilakukan kepada 648 responden di Industri Hotel di Prancis yang menyatakan bahwa WFC memiliki asosiasi positif dengan Stres Kerja yang berarti ketika tingkat WFC tinggi maka tingkat Stres Kerja juga akan tinggi. Tingkat tuntutan pekerjaan (jod demand) yang tinggi akan mengurangi waktu pekerja untuk bisa bertemu dengan keluarganya sehingga mereka akan memiliki sedikit waktu luang bersama keluarganya. Dengan demikian, Work-Family Conflict (WFC) dan Family-Work Conflict (FWC) yang berdampak pada Stres Kerja (Mansour \& Mohanna, 2018). Lebih lanjut, Hasil Penelitian terhadap 110 pegawai pemerintahan di Malaysia menyatakan bahwa terdapat pengaruh signifikan WFC terhadap Stres Kerja. Dimana ketika tingkat WFC rendah maka Stres Kerja juga akan memiliki nilai yang rendah (Jamadin et al., 2015). Penelitian yang dilakukan oleh Vickovic \& Morrow (2020) menemukan bahwa WFC memiliki pengaruh positif terhadap Stres Kerja. Dimana dari ketiga bentuk WFC, konflik berbasis waktu (time-based), konflik berbasis ketegangan (strain-based), dan konflik berbasis perilaku (behavior-based), dimensi perilaku dan ketegangan lah yang berpengaruh positif terhadap tingkat Stres Kerja. Sedangkan dimensi waktu (time based) dari 
Jurnal Riset Manajemen Sains Indonesia (JRMSI) | Vol 12, No. 2, 2021 e-ISSN: 2301-8313 http://doi.org/10.21009/JRMSI

WFC tidak berpengaruh signifikan. Hal serupa juga ditemukan dalam penelitian Armstrong et al., (2015) terhadap 441 orang sipir polisi di Amerika, dimana WFC dalam bentuk konflik perilaku kerja dan konflik ketegangan perilaku memiliki pengaruh positif terhadap Stres Kerja. Berdasarkan hasil temuan penelitian sebelumnya, kami ingin menguji kembali hipotesis penelitian sebagai berikut:

\section{H1: Work-Family Conflict berpengaruh positif terhadap Stres pada Pekerjaan}

\section{Family-Work Conflict Berpengaruh Positif terhadap Stres pada Pekerjaan}

Penelitian terhadap 514 polisi di Hongkong menyatakan bahwa FWC dan WFC berpengaruh terhadap stres kerja ( $\mathrm{Li}$ et al., 2019). Hal yang serupa juga ditemukan dalam penelitian yang dilakukan oleh Armstrong et al., (2015) dan Ofori et al., (2018) yang mengkonfirmasi adanya pengaruh positif Family-Work Conflict terhadap Stres Kerja, dimana tingkat FWC yang tinggi akan berpengaruh terhadap Stres Kerja yang juga tinggi. Lebih lanjut, penelitian yang dilakukan oleh Schjoedt (2020) menemukan bahwa FWC memiliki pengaruh positif terhadap Stres Kerja, yang dimana FWC tinggi berpengaruh pada Stres Kerja yang tinggi dan berimplikasi terhadap tingkat kepuasan kerja (Job Satisfaction) yang rendah. Berdasarkan hasil temuan penelitian sebelumnya, kami ingin menguji kembali hipotesis penelitian sebagai berikut:

\section{H2: Family-Work Conflict Berpengaruh Positif terhadap Stres pada Pekerjaan}

\section{Work-Family Conflict berpengaruh Negatif terhadap Kepuasan Hidup}

Penelitian yang dilakukan terhadap perawat di Bandung menyatakan bahwa WFC akan berpengaruh negatif terhadap Employee Weel Being (EWB). Hal ini berarti WFC tinggi akan berdampak kepada EWB yang rendah dan berimplikasi pada rendahnya tingkat kepuasan hidup perawat dan meningkatnya tekanan psikologis (Sari, 2020). Penelitian yang dilakukan pada pekerja kontrak di Amerika menunjukan bahwa WFC yang tinggi akan memiliki pengaruh pada tingkat kepuasan hidup yang buruk. Penelitian yang dilakukan oleh Yucel (2017) terhadap karyawan pekerja dan self-employed employee (penguasaha dan free lancer) menemukan bahwa tingginya WFC akan berpengaruh terhadap tingkat kepuasan hidup yang rendah. Untuk temuan tipe pekerjaan sebagai variabel kontrol didapati hasil, pengaruh negatif WFC terhadap kepuasan hidup akan lebih kuat ditemukan pada tipe pekerjaan pengusaha atau 
Jurnal Riset Manajemen Sains Indonesia (JRMSI) | Vol 12, No. 2, 2021 e-ISSN: 2301-8313 http://doi.org/10.21009/JRMSI

self employed workers. Lebih lanjut, penelitian yang dilakukan terhadap 245 pekerja di Romania menemukan bahwa WFC berpengaruh negatif terhadap tingkat kepuasan hidup. Dimana, ketika WFC yang tinggi akan berpengaruh terhadap tingkat kepuasan hidup dan tingkat kepuasan pekerja yang rendah (Cazan et al., 2019). Temuan yang serupa juga didapati di penelitian yang dilakukan Zhang et al., (2019) terhadap 236 perawat di China yang menemukan bahwa WFC berpengaruh negative terhadap tingkat kepuasan hidup para perawat. Dimana, ketika pengelola rumah sakit bisa mengurangi tingkat WFC maka hal tersebut dapat meningkatkan tingkat kepuasan hidup mereka. Berdasarkan hasil temuan penelitian sebelumnya, kami ingin menguji kembali hipotesis penelitian sebagai berikut:

\section{H3: Work-Family Conflict berpengaruh Negatif terhadap Kepuasan Hidup}

\section{Family-Work Conflict berpengaruh negatif terhadap Kepuasan Hidup}

Penelitian yang dilakukan terhadap 282 karyawan hotel bintang empat di Romania menyatakan bahwa FWC berpengaruh secara negatif terhadap tingkat kepuasan hidup karyawan hotel (Karatepe et al., 2010). Hal yang serupa juga ditemukan dalam penelitian yang dilakukan Gözü et al., (2015) terhadap 165 karyawan pekerj di Amerika yang menyatakan bahwa FWC berpengaruh negatif terhadap tingkat kepuasan hidup. Dimna, FWC yang tinggi diasosiasikan dengan tingkat kepuasan hidup yang rendah. Hasil penelitian terhadap 356 pekerja tetap di Turki menyatakan bahwa FWC dan WFC berpengaruh negative terhadap tingkat kepuasan hidup. Pengaruh ini di mediasi oleh variabel Work Life Balance (TaşdelenKarçkay \& Bakalım, 2017). Temuan serupa juga didapati dalam Penelitian terhadap 333 dan 924 pekerja di Hongkong dan Taiwan menyatakan bahwa FWC berpengaruh negatif terhadap tingkat kepuasan hidup (Chan \& Wang, 2015). Berdasarkan hasil temuan penelitian sebelumnya, kami ingin menguji kembali hipotesis penelitian sebagai berikut:

\section{H4: Family-Work Conflict berpengaruh negatif terhadap Kepuasan Hidup}

\section{Stres kerja berpengaruh negatif terhadap Kepuasan Hidup}

Penelitian yang dilakukan kepada 322 orang responden yang berasal dari Guandong Selatan menyatakan bahwa Stres Kerja memiliki korelasi negatif terhadap tingkat kepuasan hidup yang dimana ketika stress dari bekerja meningkat maka tingkat kepuasan hidup pekerja akan menurun. Tingkat kepuasan hidup yang juga rendah ditemukan ketika pekerja menemui 
Jurnal Riset Manajemen Sains Indonesia (JRMSI) | Vol 12, No. 2, 2021 e-ISSN: 2301-8313 http://doi.org/10.21009/JRMSI

banyak permasalahan dalam tempat bekerja , memiliki keterlibatan dalam pekerjaan yang rendah, stress yang tinggi dan merasakan ketidakpuasan dalam bekerja (Lambert et al., 2018). Penelitian yang dilakukan kepada 488 guru sekolah dan kampus di negara Taiwan menyatakan bahwa Stres Kerja secara negatif mempengaruhi tingkat kepuasan kerja yang dimana ketika tingkatan Stres Kerja tinggi maka akan membuat tingkat kepuasan kerja menjadi rendah(Chen, 2016). Lebih lanjut, penelitian yang dilakukan terhadap 90 orang polisi yang berada di Korea menyatakan bahwa Stres Kerja memiliki pengaruh negatif terhadap Self Well-Being yang membuat tingkat kepuasan hidup juga rendah (Ryu et al., 2020). Temuan yang serupa juga didapati dalam penelitian yang dilakukan Itzhaki et al., (2015) kepada 118 orang perawat di Israel. Hasil temuan memperlihatkan bahwa Stres Kerja yang tinggi berpengaruh negatif terhadap tingkat kepuasan hidup pekerja perawat. Berdasarkan hasil temuan penelitian sebelumnya, kami ingin menguji kembali hipotesis penelitian sebagai berikut:

H5: Stres pada Pekerjaan berpengaruh negatif terhadap Kepuasan Hidup.

\section{METODOLOGI PENELITIAN}

\section{Sampel dan Proses Pengumpulan Data}

Penelitian empiris ini dilakukan terhadap pegawai front office hotel yang tersebar di Indonesia. Penelitian ini menggunakan non probabilita sampling dengan teknik sampling judgemental. Adapun kriteria pemilihan sampel dalam penelitian ini adalah karyawan yang bekerja di hotel dengan jabatan sebagai front office .

Adapun, pertanyaan dalam kuesioner mencakup informasi mengenai demografi responden (pertanyaan mengenai jenis kelamin, usia, status karyawan, departemen dimana responden bekerja, posisi jabatan responden saat ini, domisili dan status pernikahan responden) dan juga pertanyaan yang mengukur variabel penelitian yakni Work-Family Conflict, FamilyWork Conflict, Stres kerja dan variabel Kepuasan Hidup.

Pendekatan penghitungan ukuran sample yang digunakan dalam penelitian ini mengacu pada Hair et al., (2009) dengan melihat banyaknya observed variable dikali dengan 
Jurnal Riset Manajemen Sains Indonesia (JRMSI) | Vol 12, No. 2, 2021 e-ISSN: 2301-8313 http://doi.org/10.21009/JRMSI

5 atau 10. Penelitian ini menggunakan n x 5 observasi dengan jumlah indikator pertanyaan sebesar 20. Oleh karena itu, jumlah minimum sampel yang akan diambil pada penelitian ini berjumlah 20 indikator $\mathrm{x} 5=100$ responden.

Pengumpulan data dalam penelitian ini dilakukan dengan menggunakan kuesioner digital dalam bentuk google form yang disebarkan melalui aplikasi Linkedin dan metode referal. Dari 213 data yang masuk, hanya 121 (56.81\%) data yang lolos kriteria dan bisa diolah lebih lanjut dalam penelitian.

\section{Pengukuran Variabel Penelitian}

Semua konstruk dalam penelitian ini menggunakan pengukuran yang sudah digunakan dalam penelitian-penelitian terdahulu. Variabel Work-Family Conflict dan Family-Work Conflict yang digunakan penelitian ini diukur dengan 5 buah item pertanyaan untuk masingmasing variabel yang diadaptasi dari (Netemeyer et al., 1996). Pengukuran terhadap Stres Kerja diukur dengan 6 buah pertanyaan yang diadaptasi dari penelitian (Mansour \& Tremblay, 2016) . Sedangkan Variabel Kepuasan hidup (Life satisfaction) diukur dengan menggunakan 4 item pertanyaan yang diadaptasi dari penelitian Diener et al., (1985). Semua pertanyaan dalam penelitian ini diukur dengan menggunakan skala likert yang menggunakan five-point of scale, dengan rentang jawaban 5 (sangat setuju sekali) sampai 1 (sangat tidak setuju).

\section{Analisis Data}

Pengolahan data deskriptif dalam penelitian dilakukan dengan Statistical Package for Social Sciences Programme (SPSS) versi 24. Adapun, analisis data dalam penelitian ini menggunakan PLS-SEM yang diolah dengan SmartPLS 3 (Ringle et al., 2014). Analisis PLS dalam penelitian ini dilakukan dalam dua langkah. Langkah pertama dilakukan dengan mengevaluasi Measurement (Outer) Model yang dilanjutkan dengan evaluasi inner structural model (Hair et al., 2014; Henseler et al., 2009; Wong, 2013). 
Jurnal Riset Manajemen Sains Indonesia (JRMSI) | Vol 12, No. 2, 2021 e-ISSN: 2301-8313 http://doi.org/10.21009/JRMSI

Untuk mengevaluasi common method variance bias maka penelitian ini menggunakan Harman's single factor analysis. Berdasarkan hasil uji statistic, ditemukan bahwa variance dari data penelitian adalah sebesar $30.725 \%$. Angka ini masih dibawah 50\%. Dengan kata lain, tidak terdapat common method variance bias dalam penelitian ini (Hussain, 2018).

\section{HASIL DAN PEMBAHASAN}

\section{Hasil Analisis Deskriptif}

Berikut adalah analisis data deskriptif dalam penelitian ini. Berdasarkan tabel 1, responden pekerja front office hotel dalam penelitian ini, mayoritas responden berjenis kelamin perempuan, berusia 20-25 tahun, saat ini masih berstatus sebagai karyawan kontrak dengan posisi staff, berdomisili di Jabodetabek dan sudah menikah.

Tabel 1. Hasil Analisa Deskriptif

\begin{tabular}{lccc}
\hline Items & Kategori Jawaban & Jumlah & Persentase(\%) \\
\hline Jenis & Wanita & 77 & $63.64 \%$ \\
Kelamin & Pria & 44 & $36.36 \%$ \\
Usia & 20-25 Tahun & 42 & $34.71 \%$ \\
& 26-30 Tahun & 24 & $19.83 \%$ \\
& 31-35 Tahun & 25 & $20.66 \%$ \\
& 36-40 Tahun & 11 & $9.09 \%$ \\
Status & 41-45 Tahun & 19 & $15.70 \%$ \\
Karyawan & Kontrak & 63 & $52.07 \%$ \\
Departement & Tetap & 58 & $47.93 \%$ \\
Posisi & Front Office & 121 & $100.00 \%$ \\
& Director & 2 & $1.65 \%$ \\
& Manajer & 40 & $33.06 \%$ \\
& Staff & 51 & $42.15 \%$ \\
& Supervisor & 27 & $22.31 \%$ \\
Domisili & Trainee & 1 & $0.83 \%$ \\
& Jabodetabek & 84 & $69.42 \%$ \\
Status & Luar Jabodetabek & 37 & $30.58 \%$ \\
& Bercerai & 3 & $2.48 \%$ \\
& Lajang & 54 & $44.63 \%$ \\
& Menikah & 64 & $52.89 \%$ \\
\hline
\end{tabular}

Sumber: Hasil Olahan Peneliti, 2021

\section{Analisis Measurement (Outer) Model}

Analisis Measurement (Outer) Model merupakan elemen dari model path yang berisi 
Jurnal Riset Manajemen Sains Indonesia (JRMSI) | Vol 12, No. 2, 2021 e-ISSN: 2301-8313 http://doi.org/10.21009/JRMSI

observed indikator-indikator dan hubungannya dengan construct. Analisis Measurement (Outer) Model dilakukan untuk mengevaluasi reliabilitas dan validitas construct. Di mana, reliabilitas untuk Measurement (Outer) Model PLS diukur dari internal consistency (Composite Reliability) dan Indicator Reliability. Sedangkan, untuk validitas nya diukur dari convergent validity (Average Variance Extracted) dan Discriminant Validity (Hair et al., 2014).

Suatu Measurement (Outer) Model dikatakan reliabel jika memiliki nilai Composite Reliability (CR) lebih besar atau sama dengan 0.60 - 0.70 dan nilai Cronbach's Alpha yang lebih besar dari 0.60. Sedangkan, untuk dapat dikatakan valid, suatu Measurement (Outer) Model, suatu variabel harus memiliki nilai indikator outer loadings yang lebih tinggi dari nilai cross loadings nya terhadap construct yang lain dan Fornell-Larcker Criterion yang membandingkan akar kuadrat AVE dengan korelasi konstruk laten. Dimana, akar kuadrat AVE harus lebih besar dari korelasi antar konstruk laten (discriminat validity) serta nilai Average Variance Extracted (AVE) yang lebih besar dari 0.5 dan nilai indicators outer loadings yang harus lebih besar dari 0.708 (convergent validity) (Hair et al., 2014, 2016). Berikut adalah hasil analisis model pengukuran dalam penelitian ini : 
Jurnal Riset Manajemen Sains Indonesia (JRMSI) | Vol 12, No. 2, 2021 e-ISSN: 2301-8313 http://doi.org/10.21009/JRMSI

Tabel 2. Measurement (Outer) Model Penelitian

\begin{tabular}{|c|c|c|c|c|c|}
\hline Variable & Indicators & $\begin{array}{l}\text { Outer } \\
\text { Loadings }\end{array}$ & $\begin{array}{l}\text { Cronbach's } \\
\text { Alpha }\end{array}$ & $\begin{array}{l}\text { Composite } \\
\text { Reliabilty }\end{array}$ & $\begin{array}{l}\text { Average } \\
\text { Variance } \\
\text { Extracted }\end{array}$ \\
\hline \multirow[t]{5}{*}{ Work-Family Conflict } & WFC_1 & 0.852 & 0.899 & 0.926 & 0.715 \\
\hline & WFC_2 & 0.883 & & & \\
\hline & WFC_3 & 0.903 & & & \\
\hline & WFC_4 & 0.823 & & & \\
\hline & WFC_5 & 0.759 & & & \\
\hline \multirow[t]{5}{*}{ Family-Work Conflict } & FWC_1 & 0.757 & 0.877 & 0.911 & 0.673 \\
\hline & FWC_2 & 0.763 & & & \\
\hline & FWC_3 & 0.899 & & & \\
\hline & FWC_4 & 0.880 & & & \\
\hline & FWC_5 & 0.791 & & & \\
\hline \multirow[t]{6}{*}{ Stres Kerja } & JS_1 & 0.733 & 0.870 & 0.903 & 0.609 \\
\hline & JS_2 & 0.758 & & & \\
\hline & JS_3 & 0.862 & & & \\
\hline & JS_4 & 0.794 & & & \\
\hline & JS_5 & 0.721 & & & \\
\hline & JS_6 & 0.805 & & & \\
\hline \multirow[t]{4}{*}{ Kepuasaan Hidup } & LS_1 & 0.838 & 0.879 & 0.915 & 0.730 \\
\hline & LS_2 & 0.901 & & & \\
\hline & LS_3 & 0.834 & & & \\
\hline & LS_4 & 0.844 & & & \\
\hline
\end{tabular}

Tabel 3. Fornell-Lacker Criterion (Discriminat Validity)

\begin{tabular}{lllll}
\hline & LS & FWC & WFC & JS \\
\hline Kepuasan Hidup (LS) & $\mathbf{0 . 8 5 5}$ & & & \\
Family-Work Conflict(FWC) & 0.082 & $\mathbf{0 . 8 2 0}$ & & \\
Work-Family Conflict (WFC) & -0.081 & 0.491 & $\mathbf{0 . 8 4 6}$ & \\
Stres pada Pekerjaan (JS) & -0.186 & 0.598 & 0.649 & $\mathbf{0 . 7 8 0}$ \\
\hline
\end{tabular}

Keterangan : Huruf yang Italic tebal menggambarkan akar kuadrat AVE sedangkan diagonal menggambarkan korelasi

Berdasarkan tabel 2 dan tabel 3, dapat disimpulkan bahawa model pengukuran (measurement model) dalam penelitian ini dapat diterima. Dimana, nilai Composite Reliability (CR) variabel dalam penelitian lebih besar dari 0.7 dan nilai Cronbach's Alpha yang lebih besar dari 0.60. Hal ini mengkonfirmasi reliabilitas model penelitian yang baik. Lebih lanjut, nilai AVE semua variabel dalam penelitian ini lebih besar dari 0.5. semua nilai outer loadings dari observed variabel juga lebih besar dari $0.5 \mathrm{Hal}$ ini menunjukkan bahwa model penelitian memiliki validitas konvergen yang baik. Adapun, untuk validitas diskriminan terlihat bahwa akar kuadrat AVE harus lebih besar dari korelasi antar konstruk laten.

\section{Analisis Structural (Inner) Model}

Setelah Measurment (Outer) Model penelitian dinyatakan valid dan reliabel maka langkah selanjutnya adalah melakukan analis struktural (Inner) Model. Tidak seperti CB-SEM 
Jurnal Riset Manajemen Sains Indonesia (JRMSI) | Vol 12, No. 2, 2021 e-ISSN: 2301-8313 http://doi.org/10.21009/JRMSI

yang menggunakan pengukuran Godness of Fit, pada PLS SEM, structural (inner) model didasarkan pada kapabilitas prediktif model penelitian yang dilihat dari nilai coefficient determinant $\left(\mathrm{R}^{2}\right)$, tingkat signifikansi path coefficient (nilai $\beta$ ) dan T Statistic (Hair et al., 2014, 2016; Ringle et al., 2018).

Dalam penelitian ini, nilai $\mathrm{R}^{2}$ untuk dua variabel laten endogenous, Stres kerja dan Kepuasaan Hidup adalah 0.524 dan 0.093. Angka ini termasuk dalam nilai $\mathrm{R}^{2}$ sebesar 0.524 dikategorikan moderate, sedangkan $\mathrm{R}^{2}$ dengan nilai 0.093 dikategorikan lemah (Hair et al., 2014, 2016; Henseler et al., 2009). Hal ini berarti 52,4\% variance variabel stres kerja dapat dijelaskan oleh variabel Work-Family Conflict dan Family-Work Conflict. Sedangkan, variance untuk variabel kepuasan hidup adalah hanya sebesar $9.3 \%$ yang dapat dijelaskan oleh variabel stres kerja, Work-Family Conflict dan Family-Work Conflict.

Pengujian hipotesis penelitian dilakukan dengan melihat nilai $\beta$ dan T Statistic. Nilai $\beta$ menunjukkan variasi yang diharapkan dalam suatu construct dependen untuk variasi unit dalam construct independen. Semakin tinggi nilai $\beta$ maka akan semakin besar efek substansial pada konstruksi laten endogen. Akan tetapi, nilai $\beta$ harus diverifikasi tingkat signifikansinya melalui uji T-statistik (Chin, 1998). Dalam penelitian ini, hipotesis H1, H2 dan H5 diterima sedangkan hipotesis H3 dan H4 ditolak.

\section{Gambar 2. Struktural (Inner) Model Penelitian}

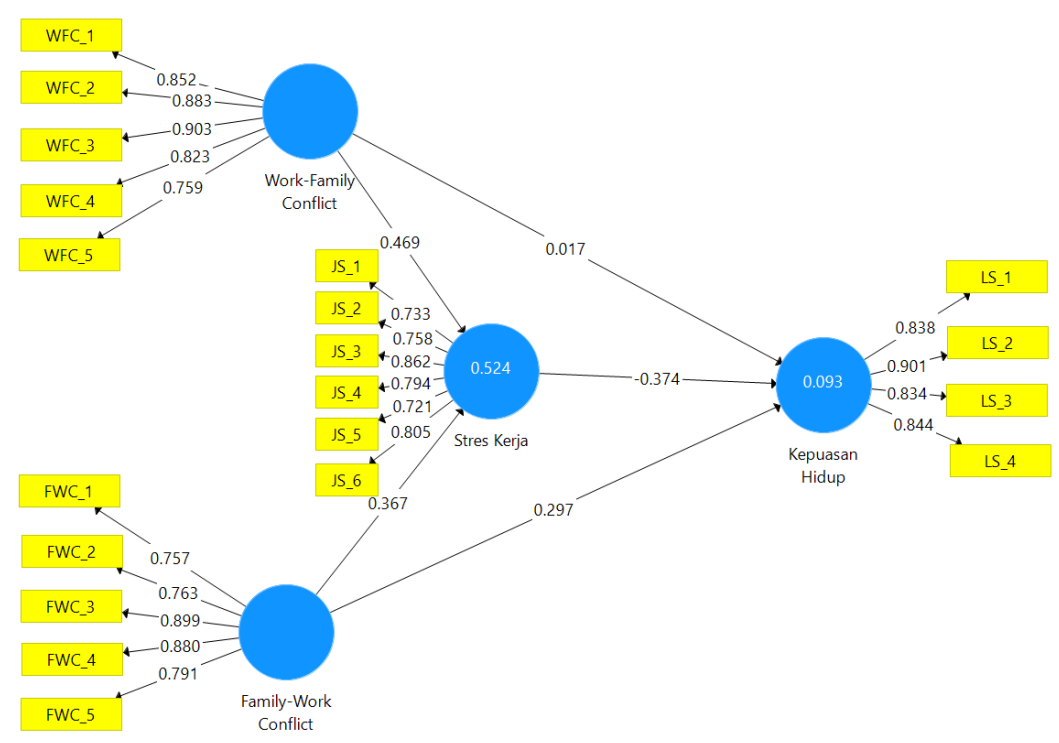

Sumber: Data Olahan Peneliti, 2021 
Jurnal Riset Manajemen Sains Indonesia (JRMSI) | Vol 12, No. 2, 2021 http://doi.org/10.21009/JRMSI

Tabel 4. Path Coefficient untuk Pengujian Hipotesis

Sumber: Data Olahan Peneliti, 2021

\begin{tabular}{|c|c|c|c|c|c|c|}
\hline \multicolumn{2}{|c|}{ Path Hypothesis } & Standardized Beta & $T$ Statistic & $P$ Value & Hasil & Uji \\
\hline H1 & $\mathrm{WFC} \rightarrow \mathrm{JS}$ & 0.469 & 5.877 & 0.000 & Diterima & \\
\hline $\mathrm{H} 2$ & $\mathrm{FWC} \rightarrow \mathrm{JS}$ & 0.367 & 4.157 & 0.000 & Diterima & \\
\hline H3 & $\mathrm{WFC} \rightarrow \mathrm{LS}$ & 0.017 & 0.139 & 0.445 & Ditolak & \\
\hline $\mathrm{H} 4$ & $\mathrm{FWC} \rightarrow \mathrm{LS}$ & 0.297 & 2.299 & 0.011 & Ditolak & \\
\hline $\mathrm{H} 5$ & $\mathrm{JS} \rightarrow \mathrm{LS}$ & -0.374 & 2.665 & 0.004 & Diterima & \\
\hline
\end{tabular}

Berdasarkan tabel 4, Hasil uji hipotesis H1 mengkonfirmasi adanya pengaruh positif Work-Family Conflict dengan Stres Kerja $(\beta=6.016, \mathrm{~T}=5.877, P=0.000)$. Dimana WorkFamily Conflict yang tinggi akan berpengaruh positif terhadap peningkatan stres kerja di kalangan pekerja front office hotel. Temuan ini sejalan dengan hasil temuan penelitian sebelumnya (Armstrong et al., 2015; Jamadin et al., 2015; Mansour \& Mohanna, 2018; Vickovic \& Morrow, 2020). Hubungan antara konflik peran dengan stress kerja juga sejalan dengan teori konservasi sumber daya (Hobfoll, 2002). Dihadapkan pada tuntutan dan ekspektasi pekerjaan yang tinggi, pekerja front office hotel akhirnya merasa kehilangan sumber daya berharga (waktu, fisik dan pikiran) yang mengakibatkan mereka mengalami kesulitan untuk menyeimbangkan tuntutan peran di pekerjaan dan di keluarga yang akhirnya mengarah pada stres kerja.

Hasil uji hipotesis H3 menujukan tidak adanya pengaruh Work-Family Conflict terhadap Kepuasan Hidup $(\beta=0.315, \mathrm{~T}=0.139, P=0.445)$ di kalangan pekerja front office hotel. Hal ini sejalan dengan hasil temuan sebelumnya yang dilakukan oleh (Karatepe \& Bekteshi, 2008; Karatepe \& Karadas, 2016) dimana, Work-Family Conflict tidak berpengaruh terhadap kepuasan hidup karyawan front office hotel. Ketika pekerja front office hotel menganggap pekerjaan sebagai sumber dari kesejahteraan hidup pribadi dan keluarga maka tuntutan pekerjaan dianggap sebagai hal yang lumrah karena anggapan bahwa pekerjaan adalah bagian dari nilai hidup yang dianggap penting oleh pekerja front office hotel.

Hasil uji hipotesis H4 menunjukkan tidak adanya pengaruh Family-Work Conflict dengan Kepuasan Hidup ( $\beta=1.901, \mathrm{~T}=2.299, P=0.011)$. Hal ini dapat disebabkan oleh sudah adanya kesalingpahaman dan kesalingpengertian dari keluarga terhadap tanggungjawab dan tuntutan pekerjaan front office hotel. Adanya dukungan keluarga secara membuat pekerja front office hotel dapat bekerja secara professional tanpa terganggu oleh tugas dan tanggung jawab nya di rumah sehingga Family-Work Conflict ini tidak berpengaruh pada kepuasan hidup. 
Jurnal Riset Manajemen Sains Indonesia (JRMSI) | Vol 12, No. 2, 2021 e-ISSN: 2301-8313 http://doi.org/10.21009/JRMSI

Hasil uji hipotesis H5 mengkonfirmasi adanya pengaruh negative antara stres kerja dengan kepuasan hidup $(\beta=-0.374, \mathrm{~T}=2.665, P=0.004)$. Hal ini sejalan dengan hasil penelitian sebelumnya (Chen, 2016; Itzhaki et al., 2015; Lambert et al., 2018; Ryu et al., 2020). Dalam konteks penelitian ini, tingkat kepuasan hidup dilihat dari pendekatan bottom-up dimana kepuasan hidup merupakan bagian dari domain kehidupan (termasuk di dalamnya pekerja) (Erdogan et al., 2012). Dalam hal ini, ketika pekerja front office hotel mengalami stres kerja yang tinggi karena tuntutan untuk melakukan pelayanan prima yang konsisten maka hal tersebut akan berdampak pada tingkat kepuasaan hidupnya secara umum.

\section{KESIMPULAN DAN SARAN}

\section{Kesimpulan}

Hasil penelitian menunjukkan mengkonfirmasi pengaruh negatif stres kerja terhadap tingkat kepuasan hidup dengan variabel Work-Family Conflict dan Family-Work Conflict sebagai antesenden di kalangan pekerja front office hotel di Indonesia. Hasil temuan penelitian ini bermanfaat untuk banyak hal. Pertama, kondisi lingkungan kerja hotel yang keras dan sulit membuat pekerja front office hotel mengalami konflik peran dalam bentuk Work-Family Conflict dan Family-Work Conflict. Tingginya WFC dan FWC di kalangan pekerja front office hotel ini menghasilkan stres yang tinggi. Padahal, staf front office hotel memegang peranan yang penting dalam proses penciptaan nilai melalui kepuasaan pelanggan. Tingkat kualitas pelayanan yang luar biasa merupakan keunggulan kompetitif yang signifikan dalam industri perhotelan. Oleh karena itu, pengelola hotel diharapkan dapat memberikan perhatian dan fokus yang lebih terhadap kondisi kerja sehingga efek WFC dan FWC terhadap stres kerja pekerja front office hotel dapat diminimalisir.

Kedua, hasil penelitian juga mengkonfirmasi adanya hubungan positif antara tingkat stres kerja terhadap kepuasan hidup secara umum pekerja front office hotel. Hal ini mengkonfirmasi penelitian sebelumnya yang dilakukan oleh Lambert et al., (2018) dimana tingkat stres kerja yang tinggi akan mengurangi tingkat kepuasan hidup secara keseluruhan. Perasaan tertekan secara psikologis yang dirasakan oleh pekerja front office hotel dari waktu ke waktu, bahkan ketika shift bekerja selesai kadang terbawa sampai ke rumah. Hal ini menyebabkan pekerja merasa tidak bahagia dalam hidup dan hal ini, mengurangi gairah mereka pada saat bekerja. Untuk memitigasi hal ini maka, pengelola hotel dapat meningkatkan kualitas dukungan sosial (social support) di tempat kerja, terutama oleh penyelia sehingga pekerja dapat mengelola stress kerja dengan baik. 
Jurnal Riset Manajemen Sains Indonesia (JRMSI) | Vol 12, No. 2, 2021 e-ISSN: 2301-8313 http://doi.org/10.21009/JRMSI

\section{Saran}

Mengingat tingkat kepuasan hidup banyak dikaitkan dengan komitmen organisasi (Vickovic \& Morrow, 2020). Adalah penting bagi pengelola hotel untuk menjaga komitmen pekerja front office sebagai ujung tombak layanan. Oleh karena itu, untuk meningkatkan tingkat kepuasan hidup pekerja front office, pengelola hotel dapat membuat kebijakan pengaturan kerja yang juga ramah keluarga, seperti dapat memberikan hak dalam fleksibilitas waktu atau kesempatan pekerja dalam berinteraksi dengan keluarga seperti cuti tahunan ataupun cuti kondisi (cuti melahirkan, dll). Selain itu, manajemen dapat memberikan program yang mendukung hubungan keluarga seperti family gathering yang dapat memberikan kesempatan masing-masing pihak mengenal lingkungan kerja dan keluarga untuk meminimalisir konflik.

\section{DAFTAR PUSTAKA}

Armstrong, G. S., Atkin-Plunk, C. A., \& Wells, J. (2015). The Relationship Between WorkFamily Conflict, Correctional Officer Job Stress, and Job Satisfaction. Criminal Justice and Behavior, 42(10), 1066-1082. https://doi.org/10.1177/0093854815582221

Bagger, J., \& Li, A. (2012). Being important matters: The impact of work and family centralities on the family-to-work conflict-satisfaction relationship. Human Relations, 65(4), 473-500. https://doi.org/10.1177/0018726711430557

BPS. (2018). Statistik Hotel dan Akomodasi Lainnya di Indonesia 2018. https://www.bps.go.id/publication/download.html

BPS. (2019). Statistik Hotel dan Akomodasinya Lainnya di Indonesia 2019. https://www.bps.go.id/publication/download.html

Cazan, A. M., Truţă, C., \& Pavalache-Ilie, M. (2019). The work-life conflict and satisfaction with life: Correlates and the mediating role of the work-family conflict. Romanian Journal of Applied Psychology, 21(1), 3-10. https://doi.org/10.24913/rjap.21.1.02

Chan, R. K. H., \& Wang, L. R. (2015). Life Aspirations: Their Impact on Family and Work Conflict and Life Satisfaction in Hong Kong and Taiwan. Asian Social Work and Policy Review, 9(3), 307-325. https://doi.org/10.1111/aswp.12070

Chen, W. C. (2016). Leisure participation, job stress, and life satisfaction: Moderation analysis of two models. Social Behavior and Personality, 44(4), 579-588. https://doi.org/10.2224/sbp.2016.44.4.579

Chin, W. W. (1998). The partial least squares approach for structural equation modeling. The partial least squares approach for structural equation modeling. In Modern methods for business research. Lawrence Erlbaum Associates Publishers.

CNN Indonesia. (2020). Menghitung Kontribusi Sektor Pariwisata Bagi Ekonomi RI. Https://Www.Cnnindonesia.Com/Ekonomi/. https://www.cnnindonesia.com/ekonomi/20200226121314-532-478265/menghitungkontribusi-sektor-pariwisata-bagi-ekonomi-ri

Coughlan, L., Moolman, H., \& Haarhoff, R. (2014). External job satisfaction factors improving the overall job satisfaction of selected five-star hotel employees. South African Journal of Business Management, 45(2), 97-107. https://doi.org/http://dx.doi.org/10.4102/sajbm.v45i2.127 
Jurnal Riset Manajemen Sains Indonesia (JRMSI) | Vol 12, No. 2, 2021 e-ISSN: 2301-8313 http://doi.org/10.21009/JRMSI

Cox, T. (1993). Stress Research and Stress Management - Putting Theory to Work. Nottingham University.

Diener, E., Emmons, R. A., Larsen, R. J., \& Griffin, S. (1985). The Satisfaction With Life Scale. Journal of Personality Assessment, 49(1), 71-75. https://doi.org/https://doi.org/10.1207/s15327752jpa4901_13

Dominici, G., \& Guzzo, R. (2010). Customer Satisfaction in the Hotel Industry: A Case Study from Sicily. International Journal of Marketing Studies, 2(2), 2-12. https://doi.org/10.5539/ijms.v2n2p3

Erdogan, B., Bauer, T. N., Truxillo, D. M., \& Mansfield, L. R. (2012). Whistle While You Work: A Review of the Life Satisfaction Literature. Journal of Management, 38(4), 10381083. https://doi.org/10.1177/0149206311429379

Esitti, B., Koleoglu, N., \& Özkan, Ç. (2015). Work-Family Conflict in Hospitality Indusrty Employees: an Application in Izmir. Journal of Life Economics, 2(2), 75-88. https://doi.org/10.15637/jlecon.74

Frone, M. R., Russell, M., \& Cooper, M. L. (1992). Antecedents and Outcomes of WorkFamily Conflict: Testing a Model of the Work-Family Interface. Journal of Applied Psychology, 77(1), 65-78. https://doi.org/10.1037/0021-9010.77.1.65

Gözü, C., Anandarajan, M., \& Simmers, C. A. (2015). Work-family role integration and personal well-being: The moderating effect of attitudes towards personal web usage. Computers in Human Behavior, 52, 159-167. https://doi.org/10.1016/j.chb.2015.05.017

Greenhaus, J. H., \& Beutell, N. J. (1985). Sources of Conflict Between Work and Family Roles. Academy of Management Review, 10(1), 76-88. https://doi.org/10.5465/amr.1985.4277352

Hair, J. F., Black, W. C., Babin, B. J., \& Anderson, R. E. (2009). Multivariate Data Analysis (7th Edition). Prentice Hall.

Hair, J. F., Hult, G. T., Ringle, C. M., \& Sarstedt, M. (2014). A Primer on Partial Least Squares Structural Equation Modeling. In SAGE (Vol. 46, Issues 1-2). https://doi.org/10.1016/j.lrp.2013.01.002

Hair, J. F., Hult, G. T., Ringle, C. M., \& Sarstedt, M. (2016). A Primer on Partial Least Squares Structural Equation Modeling (PLS-SEM) Second Edition. In Sage.

Health \& Safety Executive (HSE). (1995). Stress at Work - A Guide for Employers.

Henseler, J., Ringle, C. M., \& Sinkovics, R. R. (2009). The use of partial least squares path modeling in international marketing. Advances in International Marketing, 20(2009), 277-319. https://doi.org/10.1108/S1474-7979(2009)0000020014

Hobfoll, S. E. (1989). Conservation of Resources: A New Attempt at Conceptualizing Stress. American Psychologist, 44(3), 513-524. https://doi.org/10.1037/0003-066X.44.3.513

Hobfoll, S. E. (2002). Social and Psychological Resources and Adaptation. Review of General Psychology, 6(4), 307-324. https://doi.org/10.1037/1089-2680.6.4.307

Hussain, S. (2018). Towards nurturing the entrepreneurial intentions of neglected female business students of Pakistan through proactive personality, self-efficacy and university support factors. Asia Pacific Journal of Innovation and Entrepreneurship, 12(3), 363378. https://doi.org/10.1108/apjie-03-2018-0015

Itzhaki, M., Peles-Bortz, A., Kostistky, H., Barnoy, D., Filshtinsky, V., \& Bluvstein, I. (2015). Exposure of mental health nurses to violence associated with job stress, life satisfaction, staff resilience, and post-traumatic growth. International Journal of Mental Health Nursing, 24(5), 403-412. https://doi.org/10.1111/inm.12151

Jamadin, N., Mohamad, S., Syarkawi, Z., \& Noordin, F. (2015). Work - Family Conflict and Stress: Evidence from Malaysia. Journal of Economics, Business and Management, 3(2), 309-312. https://doi.org/10.7763/joebm.2015.v3.200 
Jurnal Riset Manajemen Sains Indonesia (JRMSI) | Vol 12, No. 2, 2021 e-ISSN: 2301-8313 http://doi.org/10.21009/JRMSI

Kahn, R. L., Wolfe, D. M., Quinn, R. P., Snoek, J. D., \& Rosenthal, R. A. (1964). Organizational stress: Studies in role conflict and ambiguity. Sage Publications Inc.

Karatepe, O. M., \& Bekteshi, L. (2008). Antecedents and outcomes of work-family facilitation and family-work facilitation among frontline hotel employees. International Journal of Hospitality Management, 27(4), 517-528. https://doi.org/10.1016/j.ijhm.2007.09.004

Karatepe, O. M., \& Karadas, G. (2016). Service employees' fit, work-family conflict, and work engagement. Journal of Services Marketing, 30(5), 554-566. https://doi.org/10.1108/JSM-02-2015-0066

Karatepe, O. M., Sokmen, A., Yavas, U., \& Babakus, E. (2010). Work-family conflict and burnout in frontline service jobs: Direct, mediating and moderating effects. $E$ a $M$ : Ekonomie a Management, 13(4), 61-73.

Karatepe, O. M., \& Uludag, O. (2008). Affectivity, conflicts in the work-family interface, and hotel employee outcomes. International Journal of Hospitality Management, 27(1), 3041. https://doi.org/10.1016/j.ijhm.2007.07.001

Kemenparekraf.go.id. (2019). KAJIAN DAMPAK SEKTOR PARIWISATA TERHADAP PEREKONOMIAN INDONESIA. https://www.kemenparekraf.go.id/post/kajian-dampaksektor-pariwisata-terhadap-perekonomian-indonesia

Khan, I., Garg, R. J., \& Rahman, Z. (2015). Customer Service Experience in Hotel Operations: An Empirical Analysis. Procedia - Social and Behavioral Sciences, 189, 266-274. https://doi.org/10.1016/j.sbspro.2015.03.222

Lambert, E. G., Jiang, S., Liu, J., Zhang, J., \& Choi, E. (2018). A Happy Life: Exploring How Job Stress, Job Involvement, and Job Satisfaction Are Related to the Life Satisfaction of Chinese Prison Staff. Psychiatry, Psychology and Law, 25(4), 619-636. https://doi.org/10.1080/13218719.2018.1473174

Lestari, E. D., \& Yuwono, M. K. (2020). The Effect of Family - Work and Work - Family Conflict on Call Center Workers ' Emotional Exhaustion With Person - Job Fit as. REVISTA CEA, 6(12), 69-85.

Li, J. C. M., Cheung, J. C. K., \& Sun, I. Y. (2019). The impact of job and family factors on work stress and engagement among Hong Kong police officers. Policing, 42(2), 284-300. https://doi.org/10.1108/PIJPSM-01-2018-0015

Mansour, S., \& Mohanna, D. (2018). Mediating role of job stress between work-family conflict, work-leisure conflict, and employees' perception of service quality in the hotel industry in France. Journal of Human Resources in Hospitality and Tourism, 17(2), 154-174. https://doi.org/10.1080/15332845.2017.1340755

Mansour, S., \& Tremblay, D. G. (2016). Workload, generic and work-family specific social supports and job stress: Mediating role of work-family and family-work conflict. International Journal of Contemporary Hospitality Management, 28(8), 1778-1804. https://doi.org/10.1108/IJCHM-11-2014-0607

Netemeyer, R. G., Boles, J. S., \& McMurrian, R. (1996). Development and validation of workfamily conflict and family-work conflict scales. Journal of Applied Psychology, 81(4), 400-410. https://doi.org/10.1037/0021-9010.81.4.400

Ofori, D., Dodoo, J., Adu, I. N., \& Gyensare, M. A. (2018). Stress as a Mediator of WorkFamily Conflict and Turnover Intention in Selected Savings and Loans Companies in Ghana. International Journal of Academic Research in Business and Social Sciences, 8(9), 770-793. https://doi.org/10.6007/ijarbss/v8-i9/4654

Ringle, C. M., Da Silva, D., \& Bido, D. D. S. (2014). STRUCTURAL EQUATION MODELING WITH THE SMARTPLS. Revista Brasileira de Marketing, 13(2), 56-73. https://doi.org/10.5585/remark.v13i2.2717

Ringle, C. M., Sarstedt, M., Mitchell, R., \& Gudergan, S. P. (2018). Partial least squares 
Jurnal Riset Manajemen Sains Indonesia (JRMSI) | Vol 12, No. 2, 2021 e-ISSN: 2301-8313 http://doi.org/10.21009/JRMSI

structural equation modeling in HRM research. International Journal of Human Resource Management, 31(12), 1617-1643. https://doi.org/10.1080/09585192.2017.1416655

Ryu, G. W., Yang, Y. S., \& Choi, M. (2020). Mediating role of coping style on the relationship between job stress and subjective well-being among Korean police officers. BMC Public Health, 20(1), 4-11. https://doi.org/10.1186/s12889-020-08546-3

Sari, W. P. (2020). Work Family Conflict, Recovery Experience, \& Employee's Weel Being in Working Women (Case Study of Nurses in Inpatient Division at Hospital in Bandung). HOLISTICA - Journal of Business and Public Administration, 11(1), 124-138. https://doi.org/10.2478/hjbpa-2020-0011

Schjoedt, L. (2020). Exploring differences between novice and repeat entrepreneurs: does stress mediate the effects of work-and-family conflict on entrepreneurs' satisfaction? Small Business Economics. https://doi.org/10.1007/s11187-019-00289-9

Stranks, J. (2005). Stress at Work: Management and Prevention. Elsevier ButterworthHeinemann.

Sulsky, L., \& Smith, C. (2005). Work Stress. Thomson Wadsworth.

Taşdelen-Karçkay, A., \& Bakalım, O. (2017). The mediating effect of work-life balance on the relationship between work-family conflict and life satisfaction. Australian Journal of Career Development, 26(1), 3-13. https://doi.org/10.1177/1038416216682954

Ten Brummelhuis, L. L., Ter Hoeven, C. L., Bakker, A. B., \& Peper, B. (2011). Breaking through the loss cycle of burnout: The role of motivation. Journal of Occupational and Organizational Psychology, 84(2), 268-287. https://doi.org/10.1111/j.20448325.2011.02019.x

Vickovic, S. G., \& Morrow, W. J. (2020). Examining the Influence of Work-Family Conflict on Job Stress, Job Satisfaction, and Organizational Commitment Among Correctional Officers. Criminal Justice Review, 45(1), 5-25. https://doi.org/10.1177/0734016819863099

Wong, K. K. K.-K. (2013). Partial Least Squares Structural Equation Modeling (PLS-SEM) Techniques Using SmartPLS. Marketing Bulletin, 24(1), 1-32. http://marketingbulletin.massey.ac.nz/v24/mb_v24_t1_wong.pdf\%5Cnhttp://www.researchgate.net/profi le/Ken_Wong10/publication/268449353_Partial_Least_Squares_Structural_Equation_M odeling_(PLS-

SEM)_Techniques_Using_SmartPLS/links/54773b1b0cf293e2da25e3f3.pdf

Yucel, D. (2017). Work-To-Family Conflict and Life Satisfaction: the Moderating Role of Type of Employment. Applied Research in Quality of Life, 12(3), 577-591. https://doi.org/10.1007/s11482-016-9477-4

Zhang, Y., Rasheed, M. I., \& Luqman, A. (2019). Work-family conflict and turnover intentions among Chinese nurses: The combined role of job and life satisfaction and perceived supervisor support. Personnel Review, 49(5), 1140-1156. https://doi.org/10.1108/PR-012019-0017

Zhao, X. (Roy), Mattila, A. S., \& Ngan, N. N. (2014). The Impact of Frontline Employees' Work-Family Conflict on Customer Satisfaction: The Mediating Role of Exhaustion and Emotional Displays. Cornell Hospitality Quarterly, 55(4), 422-432. https://doi.org/10.1177/1938965513517172 